the Committee on Comparative Systematics of the Association for the Study of Systematics. I have also to thank Dr. J. Ramsbottom for suggesting cline as the best term to denote gradation.

\footnotetext{
'Rensch, B., "Kurze Anweisung für Zoologisch-Systematische Studien", Leipzig (1934).

${ }^{2}$ Rensch, B., Arch. Naturgesch, N.F., 5, 317 (1936).

3 Witherby, H. F., "Practical Handbook of British Birds", London.

-Alpatov, W. W., Quart. Rev. Biol., 4, 1 (1929).
}

8 Thompson, D. H., Trans. Illinois State Acad. Sci., 28, 276 (1931).

'Dobzhansky, T., Amer. Nat., 57, 97 (1933).

'Schmidt, J., J. Genet., 7, 105 (1918).

${ }^{8}$ Timofeeff-Ressovsky, N. W., Arch. Naturgesch. (N.F.), 4, 245 (1935).

- Sumner, F. B., Proc. Nat. Ac. Sci., 15, 110, 481 (1929).

${ }_{10}$ Gregor, J. W., New Phytol., 37, 15 (1938).

${ }^{11}$ Miller, A. H., Univ. Calif. Publ. Zool., 38, 11 (1931).

${ }^{12}$ Linsdale, J., Univ. Calif. Publ. Zool., 30, 251 (1928).

${ }^{13}$ Miller, A. H., and McCabe, T., Condor, 37, 144 (1935).

14 Sumner, F. B., Bibliogr. Genet., 9, 1 (1932).

15 Wright, Sewall, Genetics, 16, 97 (1931).

\title{
The Geological History of Northern Central Africa
}

$\mathrm{U}^{\mathrm{n}}$ NTIL quite recently, the interior of that vast tract of Africa which lies north of the equator and west of the Nile was virtually terra incognita to the geologist. During the last few years, however, geologists of several nationalities, particularly French and Belgian, have been actively engaged in the survey of various portions of this area. As a result, a considerable amount of information on the geology of the region has become available, but is scattered among numerous publications many of which are not easily accessible to British students. The literature is, moreover, somewhat bewildering owing to the numerous unfamiliar stratigraphical terms which have been introduced.

A well condensed and useful synthesis of existing information on this subject has recently been published by Dr. K. S. Sandford (Quart. J. Geol. Soc., 93, 534 ; 1937), who was attached to Major R. A. Bagnold's expedition in 1932 for the survey of the north-western frontier of the Anglo-Egyptian Sudan, and so has been able to approach the subject from the point of view of one whose own field-work has taken him into almost the very centre of the area.

In the geological history of this area as a whole continental conditions have prevailed over long intervals of time, but three main periods are recognizable when considerable transgressions of the sea took place. An Archæan basement complex of highly metamorphosed rocks is cnvered discordantly in most districts by pre-Cambrian sediments, probably largely of marine origin. Still in pre-Cambrian times, these rocks were subjected to intense folding and considerably metamorphosed by pressure which came mainly from the east and west. In many districts these movements were accompanied by igneous intrusion. These ancient rocks, which are exposed over large areas at the present day, form the foundation of the African continent.

The Lower Palæozoic was a period of marine transgression; no Cambrian rocks have been discovered anywhere in the area, but it is probable that in the Ordovician and Silurian the sea covered most of Africa north of the equator and west of the present continental watershed. The occurrence of graptolites, brachiopods, calcareous algæ, and other organisms at a number of localities enables the beds to be dated with some degree of accuracy. South of the great ridge joining Abyssinia to the Gulf of Guinea, however, the rocks of the Katanga System, which are at least in part marine, have yielded no fossils except obscure algal remains. The dating of these rocks is, therefore, still largely a matter for dispute. As shown by Dr. Sandford, most workers favour the reference of at least the upper part of the succession (the Kundelungu Series) to the Palæozoic. The possibility of a pre-Cambrian age for the whole system cannot, however, be considered to be definitely excluded. Glacial tillites, absent from the Palæozoic of the more northerly region, occur here at more than one horizon.

Caledonian movements were mainly limited to simple elevation, so that the Palæozoic strata, in general, have remained unfolded. In the central Sahara, however, broad Caledonian folds have affected the Devonian beds, while in the south the beds of the Katanga System are involved in severe folding which may have occurred in Devonian times. These movements resulted in the progressive exclusion of the sea in later Palæozoic times, thus inaugurating a period in which the interior of Africa was once more a vast continental region undergoing denudation.

To this period belong the deposits of the Karroo System-the Lualaba and Lubilash beds of Belgian geologists-which cover wide areas in the Belgian Congo. Unlike the contemporaneous beds of South and East Africa, these are poor in fossils. To the north and north-east, the Karroo deposits pass laterally into beds classed as "Nubian Sandstone". Further information is desirable about certain beds near Guider (Léré), in the Cameroons, where brachio. pods (afterwards lost) are reported to have been found by $O$. Mann associated with fish remains described by E. Hennig as Lepidotus manni. A Jurassic age has been suggested for these beds, but there is no other evidence of a marine invasion of the area in Jurassic times.

In Cretaceous times, a renewed transgression of the sea took place, more restricted than that of the Palæozoic, but resulting, apparently, in a temporary connexion between the Tethys and what is now the Gulf of Guinea. In the Eocene, the sea appears to have covered much the same area as in the Upper Cretaceous, although there is usually a discordance between the beds of the two periods. Except marginally and very locally the sea has been excluded from the whole area in post-Eocene times. Alpine orogenic movements affected only the northern marginal belt of the Continent, but in the interior differential movements gave rise to a series of lake basins the deposits of which, sometimes silicified, are now being recognized. The Upper Tertiary was a period of much volcanic activity, which has persisted almost to Recent times.

The long list of recent publications which accompanies Dr. Sandford's paper should prove most useful to those seeking further information on the area. 